\title{
US-China Tariff War: A Gravity Approach
}

\author{
Sina E. Charandabi \\ LeBow School of Business, Drexel University \\ 3220 Market St, Philadelphia 19104, United States \\ E-mail: se456@drexel.edu \\ Farnaz Ghashami \\ LeBow School of Business, Drexel University \\ 3220 Market St, Philadelphia 19104, United States \\ E-mail: fg99@drexel.edu
}

Kamyar Kamyar (Corresponding author)

Department of Economics, The Ohio State University

1945 N High St, Columbus 43210, United States

E-mail: Kamyar.5@osu.edu

Received: June 17, 2021 Accepted: July 19, 2021 Published: August 3, 2021

doi:10.5296/ber.v11i3.18757ＵRL: https://doi.org/10.5296/ber.v11i3.18757

\begin{abstract}
Trade wars occur as a consequence of countries imposing tariffs and/or other trade barriers on one another. Such phenomenon is often a result of nationalism, unilateralism, and protectionism, and intensifies due to retaliation by different sides of the war. We use recent multinational trade data to measure the effects of single- and multi-sided tariffs on international trade. The methodology used in the paper is the structural Gravity model first introduced by Anderson and van Wincoop (2003). Theoretical implications and references of gravity equations are also presented throughout the article.
\end{abstract}

Keywords: International trade, US China tariff war, Structural gravity theory 


\section{Introduction}

Trade wars occur as a consequence of countries imposing tariffs and/or other trade barriers on one another. Such phenomenon is often a result of nationalism, unilateralism, and protectionism, and intensifies due to retaliation by different sides of the war. Economic literature frequently leans towards agreement on trade wars having no winner. This paper discusses that the US-China trade war is not an exception: "From the shop floors of Wisconsin to the factories of Asia, no one is winning President Donald Trump's trade war." (Boehm 2019) We use recent multinational trade data from China, United States, Canada, India, Germany, and Australia to measure the effects of single- and multi-sided tariffs on international trade. The methodology used in the paper is the comprehensive structural Gravity model first introduced by Anderson and van Wincoop (2003). Theoretical implications and references are presented throughout the article.

In his 2016 presidential campaign, Donald Trump castigated China due to the alleged unfair trade practices that have led into an aggravated deficit situation; and promised to pursue punishing trade policies in return. (BBC News, 2016) His administration first took steps to impose tariff and nontariff barriers on "approximately $\$ 283$ billion of U.S. imports, with rates ranging between $10 \%$ and $50 \%$. In response, U.S. trading partners, especially China, have retaliated with tariffs averaging $16 \%$ on approximately $\$ 121$ billion of U.S. exports, plunging the U.S. into its first episode of large-scale competitive tariff protection since the Great Depression of the 1930s." (Amiti et al., 2019) The initial mark-ups of the US-China trade war consisted of increased tariff rates on imported solar panels and washing machines (Lynch, 2018) and followed by on steel and aluminum (Donnan, 2018). The increased tariff rate was not solely proposed on Chinese goods; however, due to the majority of imports of the proposed items stemming in China, it appears that Chinese goods were the primary target (Boylan et al., 2020). Such tit-for-tat actions complicated the international trade policy scene and brought up questions regarding the future of trade integration.

Within the borders of the United States, customers faced a tangible increase in intermediate and final goods' prices over the course of 2018. The increased tariffs led to extensive alterations to the United States' retail supply chain network, reductions in the variety of retail products available to consumers, as well as a general increase in the prices of both imported and domestic products (Amiti et al., 2019). Evidently, tariffs also contributed negatively to the slow economic growth of China, which had already been at a critically decreasing rate (Myers et al., 2019).

Not to mention, due to the United States' and China's possession of major shares of the world GDP, the collateral damage of the trade war was felt across the rest of the world as well. In the words of the European Union's Economic and Financial Affairs Commissioner Pierre Moscovici, the damage was being sensed particularly in European countries which "rely on exports and are open to trade." For instance, more than $40 \%$ of Germany's gross domestic product consisted of exports in 2018, which is the highest of any major global economy. According to the German Finance Minister Olaf Scholz, "Uncertainty in the business community is widespread." The uncertainty was felt in countries that do not rely on exports 
too, such as Iceland, which became the first developed economy to seek aid from the IMF after a 2008 banking collapse. Despite, their rebuilt economy was threatened as a result of the American trade war (Shalal, 2019).

In early 2019, the two economies began negotiating on a trade deal after sensing the damage resulted. However, the negotiations were not strong enough to avoid the development of the incoming damage. During the negotiations, the Trump administration increased tariffs on $\$ 200$ billion of Chinese products in summer 2019 (Bryan, 2019), which were followed by an increase in tariffs from the Chinese government. The trade war was continued by China discontinuing purchase of US-made agricultural products and the U.S. Treasury Department designating China as "currency manipulator" (U.S. Department of the Treasury, 2019). Afterwards, negotiations were pursued more strongly, leading to a mutual agreement to a trade deal in the first month of 2020. According to the deal, China was to import more agricultural goods from the US, which has not been met so far due to complications caused by the COVID-19 pandemic (Boylan et al., 2020).

While the escalation towards a trade war is not novel or recent, there is a surprising absence of literature exploring the effects (Ossa, 2014). In this paper, we conduct a structural trade policy analysis and thereby estimate the exact effects of the ongoing tariff war using most recent tariff data. The framework used to conduct the comprehensive analysis is the emerging structural gravity theory that employs a PPML (Poisson Pseudo-Maximum Likelihood) regression model. The methodology and theory is elaborated on in the Materials and Methods section. We will analyze the effects of the tariff war on the world economy, as well as the US economy in particular. After verbally explaining the results in the Results section, we will conclude with a brief summary of the analysis and elaborate on open questions for further work in the Discussion section.

\section{Method}

$$
\begin{aligned}
X_{i j} & =\frac{E_{j} Y_{i}}{Y}\left(\frac{t_{i j}}{P_{j} \tau_{i}}\right)^{1-\sigma} \\
P_{j}^{1-\sigma} & =\sum_{i}\left(\frac{t_{i j}}{\Pi_{i}}\right)^{1-\sigma} \frac{Y_{i}}{Y} \\
\Pi_{i}^{1-\sigma} & =\sum_{j}\left(\frac{t_{i j}}{P_{j}}\right)^{1-\sigma} \frac{E_{j}}{Y} \\
E_{j} & =Y_{j}=Q_{j} p_{j} \\
p_{j} & =\frac{\left(Y_{j} / Y\right)\left(\frac{1}{1-\sigma}\right)}{\beta_{j} \Pi_{j}}
\end{aligned}
$$

The structural gravity system consists of equations (1) through (5), implying respectively The Structural Gravity Equation (1), Inward Multilateral Resistance (2), Outward Multilateral Resistance (3), Expenditure / Income / GDP (4), and Market Clearance Conditions (5). 
The structural gravity system above is used as the framework in this paper. The relations show the structural gravity in full details. Structural gravity system considers a world consisting of $N$ countries with each economy producing a variety of goods differentiated by the country of origin, which will be traded with the rest of the world. Supply $\left(Q_{i}\right)$ is fixed, and factory-gate price is given by $p_{i}$. Therefore, production (nominal income) at the country level is given by equation (6).

$$
Y_{i}=p_{i} Q i
$$

$E_{i}$ denotes country $i$ 's aggregate expenditure, which can also be shown by equation (7), with $\Phi_{i}>0$ representing a trade deficit on country $i$, and $1>\Phi_{i}>0$ representing a trade surplus. $\sigma>1$ denotes the elasticity of substitution of different varieties among countries trading. $t_{i j} \geq$ 1 captures fixed trade costs bilaterally imposed on both sides. The delivered price of country $i$ 's items is shown by equation (9) $X_{i j}$ denotes the cost of export goods shipped from origin $i$ to destination $j$ (Yotov et al., 2016). A comprehensive proof of equations (1) through (5) is presented in Yotov et al., 2016.

$$
\begin{gathered}
E_{i}=\Phi_{i} Y_{i} \\
p_{i j}=p_{i} t_{i j}
\end{gathered}
$$

Gravity literature considers the Poisson Pseudo-Maximum Likelihood (PPML) methodology estimation to address issues related to heteroscedasticity and zeroes (Santos Silva and Tenreyro, 2006), time-varying exporter and importer fixed effects to account for changes in the multilateral resistance constraints implied by theory (Anderson and van Wincoop, 2003; Feenstra, 2004; Baldwin and Taglioni, 2007), and time-invariant pair fixed effects to absorb unobservable barriers to trade (such as bilateral history) and to address the endogeneity of trade policy variables due to time-invariant unobserved bilateral heterogeneity (Larch, Wanner, Yotov, \& Zylkin, 2018). Therefore, the regression model used for the paper is PPML.

In order to control for the effects of the tariff, a reference country likely to be unaffected by the trade war needs to be designated. In this paper we selected Australia as the reference country; since Australia is geographically separate from the United States and China, it is a plausible choice for the reference country.

Gravity literature empirically has estimated the value of elasticity of substitution, sigma (Yotov et. al. 2016). Since the scope of this paper is not dynamic estimation with panel data, we have selected the empirically estimated value of 7 in order to estimate calculations involving sigma. This literature average value is used coherently for all further calculations.

For the course of this paper, we first estimate trade between all countries using 2006 World Trade Organization international trade data and variables elaborated on in the latter section. However, we only include data for the US, China, and their neighbors Canada \& India respectively in this paper. We also added Germany to the list as it serves as a neutral country to study the effects of the trade war. We then impose an arbitrary $30 \%$ tariff in the data where exporter is the United States and importer is China. For the second scenario, we imposed 30\% tariffs only in trades where China is the exporter and US the importer. 


$$
\text { TRADE }_{i}=\beta_{0}+\beta_{1} \text { lnDist }_{i}+\gamma_{2} \text { Cntg }_{i}+\gamma_{3} \text { Lang }_{i}+\gamma_{4} \text { Clny }_{i}+\gamma_{5} \text { Border }_{i}+u_{i}
$$

The dependent variable of the regression equation is trade for country $i$; and, on the independent variables consist of logarithm of distance, contiguity (binary variable taking the value of 1 if the countries are in the same continent and 0 otherwise), language (binary variable taking the value of 1 if the countries share the same language and 0 otherwise), colonial relationships (binary variable taking the value of 1 if the countries have had colonial relationships in the past and 0 otherwise), border (binary variable taking the value of 1 if the countries share borders geographically and 0 otherwise), Fixed Effects (factoring for unchanging variables among countries), and the error ( $\varepsilon$ ) term allowing for errors.

\section{Results}

Table 1. Baseline Gravity Estimation Results

\begin{tabular}{|l|l|l|l|l|l|l|}
\hline Trade & Coef. & Std. Err. & $\mathrm{z}$ & $\mathrm{P}>|\mathrm{z}|$ & \multicolumn{2}{|c|}{$[95 \%$ Conf. Interval] } \\
\hline lnDist & -0.7945 & 0.0485 & -16.3700 & 0.0000 & -0.8897 & -0.6993 \\
\hline Cntg & 0.5365 & 0.1141 & 4.7000 & 0.0000 & 0.3128 & 0.76019 \\
\hline Lang & 0.3495 & 0.0955 & 3.6600 & 0.0000 & 0.1623 & 0.53678 \\
\hline Clny & -0.0211 & 0.0924 & -0.2300 & 0.8190 & -0.2022 & 0.1598 \\
\hline Border & -2.5003 & 0.1200 & -20.8400 & 0.0000 & -2.7354 & -2.26508 \\
\hline
\end{tabular}

The results of the baseline gravity estimation are given in Table 1 . Generally, the pre-tariff data of 2006 show that $\log$ of distance has a negative effect on trade by 0.7945 percentage points. Contiguity has a positive effect on trade by 0.5365 percentage points. Language, likewise, has a positive effect on trade by 0.3495 percentage points. Colonial ties, however, have a negative effect on trade by 0.0211 percentage points; and border has a negative effect on trade by 2.5003 percentage points. These results are intuitive. The higher the distance is between two countries, the less the trade between them will be. Contiguity and common languages serve to integrate countries and hence have a positive effect on trade.

Table 2. Baseline Trade Figures

\begin{tabular}{|l|l|l|l|l|}
\hline Country & Changes in Total Exports & Producer Effects & Consumer Effects & Changes in Real GDP \\
\hline CHN & 0.0000142 & $-2.74 \mathrm{E}-06$ & $7.92 \mathrm{E}-07$ & 0 \\
\hline USA & 0.0000114 & $-1.91 \mathrm{E}-06$ & $-5.85 \mathrm{E}-07$ & 0 \\
\hline CAN & -0.0000111 & $-3.15 \mathrm{E}-08$ & $-2.44 \mathrm{E}-06$ & 0 \\
\hline IND & $7.72 \mathrm{E}-06$ & $-1.55 \mathrm{E}-06$ & $4.45 \mathrm{E}-08$ & 0 \\
\hline DEU & $8.97 \mathrm{E}-06$ & $-1.06 \mathrm{E}-06$ & $5.46 \mathrm{E}-07$ & 0 \\
\hline
\end{tabular}

However, the point of interest to us are the changes in trade, real GDP and the two most important trade actors - producers and consumers. In Table 2, we present the baseline trade figures. The changes in all the variables are virtually zero. This establishes the fact that any changes we see in the following table after introduction of tariffs must be a direct result of tariffs between US and China. 
Table 3. Counterfactual Scenario One

\begin{tabular}{|l|l|l|l|l|}
\hline Country & Changes in Total Exports & Producer Effects & Consumer Effects & Changes in Real GDP \\
\hline CHN & -6.0531 & -1.0746 & -0.8731 & -0.2033 \\
\hline USA & -7.2979 & 0.8277 & 1.0084 & -0.1788 \\
\hline CAN & 1.2910 & 0.5542 & 0.3976 & 0.1560 \\
\hline IND & 0.7316 & -0.0461 & -0.1390 & 0.0930 \\
\hline DEU & 0.2538 & 0.1323 & 0.1148 & 0.0175 \\
\hline
\end{tabular}

The estimation of the first counterfactual scenario one (CFL) for two-way tariffs can be seen in Table 3. As expected, total exports as well as real GDP of US and China see a decrease due to the imposed tariffs. Total exports for Canada increase as Canada tries to compensate for the lost imports from China to the United States. Producers in China suffer due to their loss of exports to the US, while producers in the United States gain due to the increase in production in order to fill the gap of lost imports from China. Consumers in China benefit due to reduced prices resulted by abundant supply. Consumers in the US, however, end up paying more as they no longer have access to lower-price Chinese imports. Due to the tariffs, we will see an increase in total exports from Canada and India. Additionally, an increase in exports in countries neighboring the US and China is observed, possibly to compensate for the lost imports in the US and China.

Table 4. Counterfactual Scenario Two

\begin{tabular}{|l|l|l|l|l|}
\hline Country & Changes in Total Exports & Producer Effects & Consumer Effects & Changes in Real GDP \\
\hline CHN & -4.9720 & -1.2742 & -1.1501 & -0.1256 \\
\hline USA & -4.9835 & 1.0505 & 1.1937 & -0.1415 \\
\hline CAN & 1.5125 & 0.6667 & 0.4891 & 0.1768 \\
\hline IND & 0.8369 & -0.0603 & -0.1697 & 0.1096 \\
\hline DEU & 0.2947 & 0.1590 & 0.1379 & 0.0211 \\
\hline
\end{tabular}

The estimation of the second counterfactual scenario two (CFL) for one-way tariffs imposed from the US to China is given in the Table 4. In this case, we still see a reduction in total exports in both countries, contrary to expectations. This loss in trade results in loss in the real GDP in both countries, although the effect is less intense than before. Producer effects are greater for China because US products are still able to make it into China, while Chinese products experience tariffs while being exported to the US. Consumer effects are also more severe than the previous case: Chinese consumers end up paying even lower than the previous scenario of two-way tariffs. The reason is that Chinese producers now have to deal with abundant supply as well as US goods entering the market; so, they end up with even lower price levels. Observing the neighbor, Canada, we see a rise in the exports, possibly to compensate for the reduced supply from China. Indian and German exports see a rise as well due similar reasons. This fact demonstrates that the US is a great consumer of Chinese goods.

\section{Discussion}

As the results show, consumers will not be better off in case of imposing tariffs by huge 
trading economies as US and China. Contrary to the public belief described in the first part, however, the rest of the world sees an increase in exports due to trade diversion effects.

In the first month of 2020, the US-China tariff war evolved into a trade deal. It was made possible by President Trump signing an initial trade deal with China, which brought the economically destructing fight with China, one of the world's largest economies, to an end. The hope was for China and the United States to open their markets to one another's companies, increase the level of exports and protect either sides' technology and trade secrets. Additionally, China committed to buying an additional \$200 billion worth of American goods and services by 2021 and promised to ease some of the barriers it had placed on trade with the United States (Swanson \& Rappeport, 2020). However, to the date China could not fulfill the promises made in the deal due to complications caused by the COVID-19 pandemic. Time-permitting, we will see how either sides' further actions and their results impact us.

\section{Acknowledgments}

The authors wish to thank Dr. Yoto Yotov of Drexel University for his helpful comments and guidance, without whom the creation of this project would not have been possible. We also thank Mr. Abdul Basit, M.Sc. Economics, for his help.

\section{References}

Amiti, M., Redding, S., \& Weinstein, D. (2019). The Impact of the 2018 Trade War on U.S. Prices and Welfare. NBER Working Paper Series. https://doi.org/10.3386/w25672

Anderson, J. E., \& van Wincoop, E. (2003). Gravity with gravitas: a solution to the Border puzzle, American Economic Review, 93, 170-192.

https://doi.org/10.1257/000282803321455214

Baier, S. L., \& Bergstrand, J. H. (2007). Do free trade agreements actually increase members' international trade?. Journal of International Economics, 71, 72-95.

https://doi.org/10.1016/j.jinteco.2006.02.005

Baldwin, R., \& Taglioni, D. (2007). Trade effects of the euro: a comparison of estimators, Journal of Economic Integration, 22, 780-818. https://doi.org/10.11130/jei.2007.22.4.780

Bazzazan, F., Ghashami, F., \& Mousavi, M. H. (2017). Effects of targeting energy subsidies on domestic electricity demand in Iran, International Journal of Energy Economics and Policy, 7(2), 9-17.

BBC News. (2016). Trump Accuses China of 'Raping' US with Unfair Trade Policy.

Boehm, E. (2019). Trade Wars Have No Winners. Reason.

Boylan, B. M., McBeath, J., \& Wang, B. (2020) US-China Relations: Nationalism, the Trade War, and COVID-19. Fudan J. Hum. Soc. Sci. https://doi.org/10.1007/s40647-020-00302-6

Bryan, B. (2019). Trump Just Ramped Up Tariffs on $\$ 200$ Billion Worth of Chinese Goods. Here Are All the Products That Will Get Hit. Business Insider. 
Donnan, S. (2018). Donald Trump to Slap 25\% Tariff on Steel Imports. Financial Times.

Feenstra, R. C. (2004). Advanced International Trade: Theory and Evidence, Princeton University Press, Princeton, NJ.

Ghashami, F., \& Kamyar, K. (2021). Performance Evaluation of ANFIS and GA-ANFIS for Predicting Stock Market Indices. International Journal of Economics and Finance. https://doi.org/10.5539/ijef.v13n7p1

Ghashami, F., Kamyar, K., \& Riazi, S. A. (2021). Prediction of Stock Market Index Using a Hybrid Technique of Artificial Neural Networks and Particle Swarm Optimization. Applied Economics and Finance. https://doi.org/10.11114/aef.v8i3.5195

Isidore, C. (2018). 'Trade wars are good?' Two words: Great. Depression. CNN.

Kamyar, K (2020). Effect of Unemployment Length on Employment Expectations. Undergraduate Economic Review.

Larch, M. V., Wanner, J., Yotov, Y. V., \& Zylkin, T. (2018). Currency Unions and Trade: A PPML Re - Assessment with High - Dimensional Fixed Effects. Oxford Bulletin of Economics and Statistics, 81(3), 487-510. https://doi.org/10.1111/obes.12283

Lynch, D. J. (2018). Trump Imposes Tariffs on Solar Panels and Washing Machines in First Major Trade Action of 2018. The Washington Post.

Mohaghegh, M., \& Valipour, A. S. (2021). Triggering Economic Growth:Trade Liberalization as the Prominent Factor in Less-developed Countries. Business and Economic Research. https://doi.org/10.5296/ber.v11i2.18491

Myers, J., Chang, A., Gringlas, S., \& Yu, M. (2019). Has The Trade War Taken A Bite Out Of China's Economy? Yes - But It's Complicated. NPR.

Ossa, R. (2014). Trade wars and trade talks with data. American Economic Review, 104(12), 4104-46. https://doi.org/10.1257/aer.104.12.4104

Santos Silva, J. M. C., \& Tenreyro, S. (2006). The log of gravity. Review of Economics and Statistics, 88, 641-658. https://doi.org/10.1162/rest.88.4.641

Shalal, A. (2019, October 21). Fallout from Trumps trade wars felt by economies around the world. Reuters.

Swanson, A., \& Rappeport, A. (2020). Trump Signs China Trade Deal, Putting Economic Conflict on Pause. The New York Times.

Larch, M., Monteiro, J. A., Piermartini, R., \& Yotov, Y. V. (2016). An Advanced Guide to Trade Policy Analysis: The Structural Gravity Model, WTO and UNCTAD.

U.S. Department of the Treasury. (2019). Treasury Designates China as a Currency Manipulator. Press Release. 


\section{Copyright Disclaimer}

Copyright for this article is retained by the author(s), with first publication rights granted to the journal.

This is an open-access article distributed under the terms and conditions of the Creative Commons Attribution license (http://creativecommons.org/licenses/by/4.0/). 